\title{
The problem(s) with cities: Analyzing the need for greater municipal empowerment in Canada
}

\section{Joy Ciccarelli-Shand - Dalhousie University}

Canada's big cities face big, complex problems that undeniably hamper their ability to govern effectively. In addition to the fact that they are highly diverse and culturally distinct from their surrounding regions, many structural issues exist within the architecture of big city governments that make the act of governing extremely difficult, and the result is an arguably poorer quality of life for urban citizens. Not only are urbanites underrepresented in the federal system, meaning that the issues they face in their day-to-day lives are less discussed in Ottawa, but urban-based minorities, including racialized and poor Canadians, are further marginalized. Municipalities, presided over by provincial governments, have little control and minimal ability to address the needs of their citizens in serious and thoughtful ways: this is not only harder on the administrators of big cities, who feel significant frustration at their own impotence, but is also hard on citizens who are unable to hold their city governments accountable for anything, including the bad behaviour that sometimes results (Slayton 2015, 1-2).

The consequences of this situation are far-reaching: Canadian cities are less competitive globally because they are "hobbled" with regards to the kind of policy they can create and implement, weakening their ability to drive vital regional growth in the information age (Broadbent 2008, 229; Courchene 2007, 10). Perhaps the biggest issue for cities is that they do not have the fiscal capacity to sustain all of the programming and services they are meant to be responsible for. Again, this results in frustration for citizens, and observations from the provinces that cities are not competent to handle greater autonomy. Theoreticians have offered numerous possible solutions to resolve this woeful state of affairs, including city restructuring, "devo-max", greater federal involvement, and the creation of city-provinces in order to achieve complete autonomy. In light of the litany of serious problems facing big cities, the best solution is their constitutional entrenchment as either city-provinces, or as a defined third order of government with clearly delineated powers. However, despite this being the best solution for these cities, constitutional entrenchment is extremely unlikely to occur due to the strict amending formula: the provinces will always choose to retain the powers that they have, rather than redistributing them.

The study of municipal autonomy is generally fraught with ambiguity as to what truly constitutes a "big city". At what point is a city large enough to consider independence from its province? Various definitions have been established, but there is no methodological 
standard or metric ${ }^{1}$. Primary consideration has been for population numbers (although not for rate of population growth, interestingly), and for a vague sense of diverseness. Any definition must also account for the eventuality that more cities will become "big cities" in the future. For the purposes of this article, I will consider Census Metropolitan Areas (CMAs) with a population of two million citizens or greater to be "big cities". Toronto, Montreal, and Vancouver meet this criteria, according to the 2011 census ${ }^{2}$. Based on population predictions for Canadian CMAs in 2015, Calgary, Edmonton, and Ottawa-Gatineau will become "big cities" in the relatively near future ("Population of Census Metropolitan Areas", Statistics Canada 2016).

The first section of this paper will provide context to the debate by reviewing the most critical problems faced by big cities today, and exploring why specifically the current model for governing them is failing. The second section will elucidate the various alternative possibilities for modifying the system of municipal governance towards greater autonomy. In the final section, I advocate for the creation of city-provinces as the best way to resolve the numerous problems that exist. I also offer some possibilities as to how a change to this kind of model might work, and finally, discuss why this solution will, in all likelihood, never come to pass.

\section{Big City, Big Struggles}

Before looking at the various alternatives to the current model of city government, it is necessary to understand what the existing difficulties are. To begin with, Neil Bradford (2002) claims that Canada is more urbanized now than ever before, with nearly $80 \%$ of its population residing in cities (4; Broadbent 2008, 14; Dewing, Young, and Tolley 2006, 4). For big cities, population is a problematic strength: a large population generates significant wealth, but requires much more in terms of service provision and administration. Cities are much more diverse than the provinces in which they reside, and are also where some of Canada's most critical social issues materialize, including racism and radical social diversity, income disparity and poverty, immigrant settlement, crime, environmental degradation, and

"socio-spatial segregation", also known as ghettoization (Andrew 2001, 100; Bradford 2002, 8-11; Broadbent 2008, 99). Big cities are largely responsible for immigrant settlement and transitional housing, as this is where large immigrant communities already exist, along with the services necessary to ease the arrival process. Toronto alone receives nearly $50 \%$ of all immigrants to Canada, and this diversity brings a different set of needs for services, especially in the areas of health care and education (Broadbent 2008, 105, 194-95; Andrew

1. For example, in his book, Broadbent (2008) describes the Big City Caucus and the group of "C5 Mayors" (Toronto, Montreal, Vancouver, Calgary, and Winnipeg), both of which are subgroups of the Federation of Canadian Municipalities, as options for determining "big cities" (9-12).

22. Population statistics for 2011 are as follows: Toronto - 5,583,064; Montreal - 3,824,221; Vancouver - 2,313,328. Up and coming "big cities" might include Ottawa-Gatineau (1,236,324), Calgary $(1,214,839)$, and Edmonton $(1,159,869)$. 
2001,101-02). While managing these issues is fundamental in big cities, these are needs that simply do not exist in rural areas (Broadbent 2008, 104; Bradford 2002, 4).

Settlement services offer a good example of one area in which big cities have expertise, and yet are stymied in policy making and program design by a lack of political power, despite being able to provide the most immediate and appropriate responses on the ground (Broadbent 2008, 104-06; Bradford 2002, 12). Cities are unable to contribute their significant first-hand knowledge in policy making because they do not participate adequately in the mechanisms of national governance. For example, big cities do not have the representation by population that they ought to in the House of Commons, because of the rapid rate of urbanization and the slow rate of seat redistribution: on average, rural ridings comprise approximately $30 \%$ fewer voters than urban ridings $\mathrm{do}^{3}$, making each individual rural vote carry more electoral weight (Broadbent 2008, 14-15). Not only is this undemocratic, but it leads to a rural or regional slant in policy making, and biases the discussion towards issues concerning those parts of Canada. For instance, large cities are focused on the "new economy" (service- and knowledge-based), whereas much of the rest of the country is still concerned with the "old economy" (staples and resource-based) (Broadbent 2008, 4, 19, 226; Bradford 2002, 5). This has pushed cities to feel "tired of being the cash cow of Confederation" (Broadbent 2008, 4): while cities funnel capital into Canada, few of their issues are addressed ${ }^{4}$.

This has brought other concerns about the ability of cities to be self-determining and self-governing to the fore. Broadbent (2008) in particular highlights the way in which archaic constitutional structures are limiting the competitiveness of Canada's big cities in the global economy (71), and claims that there is a "disconnection" in that the structure of our constitution no longer corresponds to that of our society and economy $(5,13$; Courchene 2007, 8). Although big cities are the economic engines of Canada's knowledge economy, disempowered cities are not able to compete at their best within the global marketplace, slowing regional growth. In order to be competitive, cities need to behave more like the autonomous, deterritorialized nodes in a rhizomatic world-wide network of locales.

3. According to Broadbent (2008), constitutional clauses ensure that regions with diminishing populations retain a set number of seats in the Senate and the House of Commons, which biases the parliamentary structure against those areas that are fast-growing. Further, constitutional provisions allow for a $25 \%$ variation in riding size, meaning that the smallest and largest ridings have a size difference of $60 \%$ in the number of eligible voters. These issues perpetuate inequality in the voting system (222-23).

4. Although the "urban-rural divide" in voting preference has been strongly mythologized in Canada, this theory (broadly, that rural areas vote conservatively and urban areas vote progressively) does not play out neatly in terms of seats, at least in recent elections. Conservatives still have strong showings in some urban ridings, and recently, more centrist or progressive are winning rural ridings. One place where the urban-rural divide does occur reliably is in the province of Alberta. Although the premise of an urban-rural divide has a strong presence in policy making, rhetoric, and debate, it has been shown inconsistently when it comes to the realities of seat distribution by party (Libin 2011; CBC Canada Votes 2015). However, this does not detract from the fact that rural votes count for more than urban ones do, and that rural concerns are more present in debates; rather, it simply means that rural voters do not always choose Conservative politicians to voice those concerns. 
Effectively, as the world becomes extra-local, city governance is becoming more important, while national governance becomes less so (Leo 2006, 482). Because rigid, traditional hierarchies are disadvantageous, Bradford (2002) argues that big cities now have a critical opportunity for democratic engagement with citizens, if they can be given the political room and the financial support to do so (58; Leo 2006, 482-84; Courchene 2007, 11).

Courchene (2007) articulates several reasons for the critical importance of big cities, which generally follow Richard Florida's theory of the "creative class"5: big cities play host to dense clusters of human capital, as young, talented, educated, and highly-skilled workers are attracted to places where innovation, diversity, openness, and acceptance are culturally normative, and these clusters in turn draw knowledge-based industry to Canada (12; Courchene 2005, 4-5). Canada's big cities, however, are "falling short of this promise" to propel growth, because they are not being supported by higher levels of government to build infrastructure, improve public transit, and manage social services; therefore, Canada needs to "bridge the gap" for its biggest cities, in order to make them more internationally competitive (Courchene 2007, 12, 32). Crucially, this argument has a flip side: Canadian cities have simultaneously seen a rapid upsurge in the service economy, a de-skilled and flexibilized labour market which enables the knowledge economy. Big cities host not only the creative class, but also the lower class of "denizen" service workers who are disproportionately female, racialized, and precarious; fundamentally, this creates disparities between certain segments of the population that big cities must have the power to address if they wish to avoid extreme polarization in society (Standing 2011, 14; Broadbent 2002, 89; Andrew 2001, 101-02).

In the Constitution Act of 1867, "Municipal Institutions" are placed squarely under provincial jurisdiction in s. 92 (8): they are the complete responsibility of the provinces, with "no control over their own destinies" (Dodek 2013, 63; Broadbent 2008, 67). Broadbent (2008) claims that the ability of a government to control its own destiny is fundamental for effectiveness: because cities lack this control, they cannot provide citizens with what they need, want, and reasonably expect (Slayton 2015, 2). Currently, city governments cannot be held accountable for their failings, because they lack the authority to deliver on what they are expected to provide, and can "use their powerlessness as a shield, or a crutch" (Broadbent 2008, 68). They do not have control over even the most basic elements of their administration, such as how many seats there are on city council, and are often undermined by provincial bodies $(71,77-78)$. Provincial governments can also rearrange municipal structures at will, as happened when Toronto was forcibly amalgamated with its surrounding cities by the Harris government in 1998, over the objections of both the cities involved and most of their citizens (75; Dewing, Young, and Tolley 2006, 2). Historically, in

5. For more information, see: Florida, Richard. "Cities and the creative class". City \& Community 2 (1), 3-19. DOI: $10.1111 / 1540-6040.00034$ 
big cities, "[g]ood day or bad, someone else made the decisions" (Broadbent 2008, 76), largely because the capacity for financing policy and programs resided with other levels of government.

According to Slayton (2015), the structural problems of big city governance have only been worsened by the poor leadership they have seen. Several mayors in Canada's recent history have faced criminal charges, scandals, accusations of incompetence, and been subject to inquiries, due in part to the unaccountable nature of the job (1). Even the good mayors, he claims, are "constrained, hampered, hobbled and frustrated by the constitutional, economic and political reality of Canadian cities" (4). Theorists agree that by infantilizing big city governments, the provinces have encouraged them to behave childishly. As Broadbent (2008) claims, when the authority of cities is divided from the fiscal capacity to meet their responsibilities, "the behaviour of city governments begins to disintegrate" (76-77; Andrew $2001,100)$. The provinces in turn respond to the abhorrent behaviour of city officials and administrations with the claim that they cannot handle the meagre responsibilities they do have, let alone anything more.

Arguably the biggest problem that large cities face is a dearth of fiscal tools with which to raise funds, including broader powers to tax and the use of debt instruments. As Broadbent (2008) says, cities lack the "fundamental basis of effective government", because "to tax is to govern" (80). Right now, big Canadian cities are "particularly handcuffed fiscally": they rely heavily on property taxes for revenue, to the extent that approximately $50 \%$ of their income is generated this way, as compared to it constituting only $15 \%$ of income for US cities (Broadbent 2008, 80; Bradford 2002, 156; Courchene 2007, 167). This is highly problematic, as the values of property do not keep pace with the rest of the economy, in contrast to the consumption and income taxes that other levels of government are permitted to levy (Broadbent 2008, 80; Dewing, Young, and Tolley 2006, 3; Courchene 2007, 18). Generally speaking, property taxes can be considered a regressive form of taxation, as they burden most those with the least ability to pay.

Because cities rely on property taxes, user fees, and provincial grants to operate, it is difficult for them to run financially risky programs such as ones providing assisted-living facilities or low-income housing, no matter how necessary they are. Provincial backing is unpredictable, and therefore cities are incapable of establishing these kinds of initiatives (Broadbent 2008, 90). Big cities are often discouraged from developing long-term solutions because they cannot establish long-term financing, a major challenge as they have, on the balance, problems that can only be solved in the long-term (Dewing, Young, and Tolley 2006, 3). Bradford (2002) refers to the fiscal incapacity of big cities to meet their administrative

6. Bradford cites the reliance of US cities on property tax revenues at $21 \%$ in 2002.

7. For a broader international comparison of city expenditures, revenues, and taxation practices, see Courchene (2007), 12-21. 
and service obligations as the "resource-responsibility imbalance", and claims that it needs to be redressed urgently (29). Ideally, any new mode of governance for big cities would see the unification of authority and accountability through the adoption of new, more appropriate fiscal tools (Broadbent 2008, 80-81).

Regardless of how change is made to city governance structures, there can be no question that it is urgently needed. Cities are distinct from suburban or rural areas, are highly diverse, face an enormous influx of immigrants every year, are densely populated, unaccountable, and financially unfeasible. It is to the different options for how this change might be accomplished that I will now turn.

\section{Big Cities Done Better?}

There are many alternatives available for restructuring Canada's largest cities. Some pathways to empowerment include devolution-maximum ("devo-max"), increasing federalmunicipal relations, establishing the right to self-government in a charter, and gaining provincial status and powers via constitutional amendment, among others. Each of these will now be discussed individually.

"Devo-max", or devolution-maximum, is one such solution proposed by Philip Slayton (2015). This is a term borrowed from the United Kingdom to describe the place that Scotland has been given within the unitary state system as a means to avoid secession. Devo-max would mean that the Canadian federation would grant as much autonomy to the big cities as possible, without relinquishing sovereignty over them (5; Gander 2014). In the Canadian context, the process would involve conference consultations with the premiers and prime minister to acknowledge the problems, and then the (re)negotiation of a charter for every big city. According to Slayton (2015), each of these charters will hinge on a procedural entrenchment clause, which would require any alteration to the charter to adhere to its own rules, including its potential repeal. This would prevent the province from unilaterally changing the foundation of city governance as it would a regular piece of legislation, which is the case currently with Municipal Acts (232-33). While the charter would still be nonbinding for the province, Slayton (2015) theorizes that it would be greatly disinclined to ignore a charter because of the possibility of facing substantial political repercussions for doing so (much like the use of the notwithstanding clause in the Charter of Rights and Freedoms). For Slayton (2015), there are three key things that need to be included in these city charters: unlimited financial freedom, better ethical rules for officials and politicians, and the introduction of partisan politics at the municipal level. While the conditions of devomax are similar to those that currently exist, Slayton (2015) claims that the changes he suggests would make a "simple but substantial" difference (233-35). 
Another alternative presented by Broadbent (2008) is to make incremental changes to municipal governance structures through relationships with the federal government (168). Right now, the federal government is largely prevented from direct intergovernmental relations with municipalities by the constitution; indeed, any relations that do happen occur by way of the provinces, or through the lobbying of the Federation of Canadian Municipalities. However, the federal government can still make a financial impact by giving individuals funds directly, through either a grant structure or via the tax system (i.e., scholarships for university students, or rent supplements and tax credits on mortgage payments for low-income Canadians) (173-78). Ideally, the federal government would listen to the needs of big cities and provide funding for the issues that the municipal governments feel are most salient. The argument here is that the biggest issues facing cities are really national issues, such as homelessness or public transit, which are played out most often at the municipal level (169). One example might be making individual transit passes taxdeductible, so that people who take public transit over driving see some direct benefit and are enabled to keep doing so. The federal government could also act as a guarantor for municipalities when they need to take out bonds, so that they have the capital to invest in large, long-term projects such as infrastructure building (173). In addition to these measures, the federal government might take the step of consulting city governments whenever an issue at hand will affect them, thereby privileging their local expertise (18182).

Although the federal government might be able to engage municipal funding successfully in this way, there are certain problems that arise with these types of arrangements. One such problem is that while these measures have the benefit of targeting support to where the need really is, and dispel potential concern about the province diverting federally allocated funds for other purposes, they still leave the federal government open to confrontation with the provinces over jurisdiction regarding big cities, as is the case right now. Another problem with the aforementioned solutions is that municipalities remain dependent on the goodwill of a higher-level government (although the federal level is perhaps a more natural ally than the province) (Broadbent 2008, 182). Lastly, the kind of change that cities see as the norm now is incremental and needs-based: while having the benefit of ensuring that real need exists before changing relationships of power, it is also an extremely slow and difficult process that does not cohere well with a global pace $(95,185)$. A significant problem with federal grants and tax measures is that they would continue to offer only incremental levels of change. While these steps are "practical and attainable", they often take "years and sometimes decades" to accomplish (185). Instead, Broadbent (2008) argues that " $[\mathrm{r}]$ ather than telling cities how to behave one issue at a time, governments should give the cities broad authority and responsibility to control their own destinies" (18687). 
Leo (2006), relying on Courchene $(1995)^{8}$, claims that the ability to give greater autonomy to the largest cities through the creation of asymmetrical governance already exists within the Canadian model and practice of federalism ("federalism as process"), as demonstrated by the asymmetry provided for Quebec in the federal-provincial context. Essentially, his argument is that the flexibility required to accommodate difference is built into the federal system; therefore, there should be no need to impose rigidity on municipal governing structures by constitutionalizing them, when their needs can be adapted to through the federal process (486-87). Some possibilities for these types of arrangements that can avoid constitutional change include federal-provincial-municipal ("tri-level") agreements and accords, and the inclusion of authentic local participation through consultation in the decision making process (489-90). Leo (2006) cites multiple examples of this style of inclusive agreement, including the Social Union Framework Agreement (SUFA) and the Neighbourhood Improvement Programme (NIP) in Winnipeg (490).

Leo (2006) also imagines a Canada of "non-territorial federalism", where sovereignty can be "unbundled". This requires working beyond traditional hierarchical structures and instead adopting a mode of government that is more interdependent, overlapping, and perhaps less transparent. Levels of government, he says, would cooperate, sharing responsibilities and working together on some initiatives. Furthermore, when we consider this seriously, "it becomes obvious that hierarchies of sovereignty were never as tidy, or jurisdictions as airtight, as many imagined them to be". This is how the world operates today: with increasing need for flexibility and with a sense of borderlessness. The result would be a shift from "government" to "governance", where multiple levels would collaborate on issues of importance, and govern simultaneously. At the same time, communities would participate in decision-making, even down to the level of neighbourhoods, so that agreements could be reached from the bottom-up (Leo 2006, 491-93; Courchene 2007, 28).

There are several ways that this might be brought about: federal transfers might be tied to community level consultation and participation, or municipal governments might participate in the process of creating agreements between levels of government. Regardless of the method, "deep" federalism would require that national policy address community needs in a way that would likely result in the further decentralization of the Canadian state (Leo 2006, 502-03). Other theorists agree: Bradford (2002) promotes the "joint responsibility" of governments and citizens, claiming that the outcome is better in the long term, that policy is more effectively implemented, and that this method creates "ownership of problems and responsibility for solutions [which] is shared by the stakeholders" (52). While this seems aimed at supporting communities and customizing policy to fit specific needs, it also represents in certain aspects the neoliberalization of governance, through the

8. From Courchene, T. J. (1995). Celebrating Flexibility: An Interpretive Essay on the Evolution of Canadian Federalism. Montreal: CD Howe Institute. 
downloading of responsibility onto citizens and government withdrawal from decisionmaking. In addition, though asymmetrical federalism is indeed useful in accommodating large minority groups, such as the French Canadian population of Quebec, it is arguably less possible and less appropriate to accommodate the needs of urban Canadians even with the inherent flexibility of federalism, as they constitute a majority population.

Finally, some may argue that cities are now addressing their issues well enough after having established city charters. These charters are one strategy that cities are currently using to modify the arrangements that exist between them and their provincial governments. The Greater Toronto Charter, for example, was established in 2006, in order to help to address the challenges of urbanization through the articulation of more extensive powers (Broadbent 2008, 8). The purpose of a city charter is to structure the unique laws that apply to that city, including any distinctive powers or responsibilities that do not correspond with those of other municipalities in the region. This creates a unique system of governance for a specific city, so that its needs and circumstances are recognized beyond the administration of blanket provincial legislation (Keil and Young 2003, 92; Broadbent 2008, 8-10).

The principal benefits of chartering for cities are that it allows them to tailor legislation while remaining under provincial jurisdiction, it makes governing more flexible, and it may increase governing capacity so that autonomy is more possible in the future. However, there are drawbacks, too: city charters can be unilaterally amended or repealed by the province like regular legislation (although the province must consult with the city before doing so). Charters may also create different governing arrangements and structures for many municipalities in one region, resulting in a "patchwork" of governance (Dewing, Young, and Tolley 2006, 19; Leo 2006, 484-85). According to Courchene (2007), city charters establish powers for big cities in Canada that most international cities of comparable size already have; therefore, to do the same thing in Canada should be easily achievable (29). Importantly, Courchene (2007) emphasizes that big cities in Canada differ substantially and in numerous ways from the most other municipalities, which warrants that they receive distinct treatment (33; Keil and Young 2003, 95). Indeed, many municipalities would not have the desire or capacity to take on the powers given in a charter, and benefit in many ways by pooling resources through the provincial government (Broadbent 2008, 83).

Having reviewed multiple solutions for enhancing municipal autonomy, and after presenting a critique of both the benefits and drawbacks for each alternative, I will now discuss and advocate for one final possibility: that of empowering big cities within the constitution via the creation of city-provinces. 


\section{Big Cities Need Big Changes}

While the options described above offer workable ideas, constitutional entrenchment is the best option for effecting concrete change and empowerment for big cities. Alan Broadbent (2008) offers a bold vision for this: he proposes that the three biggest Canadian cities (Toronto, Vancouver, and Montreal) be transformed into city-provinces, despite the difficulties inherent in any attempts to amend the constitution. The time has come - as he says, "we cannot any longer afford to be captives of our constitutional documents if we hope to be masters of our future" (20). Not only do these cities have large population bases, unlike some of the existing provinces, but they are significantly distinct from their regional contexts in terms of identity and extreme heterogeneity. Therefore, he claims, a "one size fits all" approach to municipal legislation cannot feasibly work, as "it will fit only [big cities or smaller municipalities] or neither" (99, 228-29). Ultimately, big cities must have a legal "seat" in government: in order for the federation to continue to work, Broadbent (2008) says, "partners must have equal status and equal rights at the table" (81).

To review, there are numerous reasons to entrench city provinces in the constitution, aside from the huge population disparities that exist between many of the provinces and the largest cities 9 : big cities have more complex and diversified economies that vitalize their whole regions, they are where the majority of immigrants settle, and they are already an amalgamation of smaller localized identities (189). Big cities also have special needs that do not exist in other parts of their regions: their healthcare systems function differently, their school curriculums teach different things and require different resources, they need to administer settlement services, they have a much greater need for low-income and transitional housing, they experience the most urgent need for environmental policy, they need public transit, their land use decisions and patterns of growth are different, and they require much stricter gun laws (191-98).

There are several ways that the creation of city-provinces might occur. The most radical would be for an existing province to make the change unilaterally, which it has the power to do by regular vote; however, this would in all likelihood have terrible political consequences (Broadbent 2008, 202). A Royal Commission could be struck to assess the situation of big cities and to determine what the new arrangements would look like, and eventually recommend the incorporation of city-provinces (203). Similarly, the Senate could be called upon to research different options for city-province development via committee (204). Interestingly, no consideration has been given in the literature to the possibility of giving big cities the status of territories, which would create "provinces-in-waiting" by allowing the federal government to devolve the powers of a province slowly over time, and

9. According to Broadbent (2008), the Greater Toronto Area alone has a larger population than each of the Maritime and Prairie provinces individually, and the Greater Golden Horseshoe, an area extending from Peterborough to Georgian Bay and down to Niagara, has a larger population than all of the Maritime and Prairie Provinces combined. Further, Montreal and Vancouver each hold as many people as six out of the ten provinces do (187). 
provide flexibility for these entities to be more or less dependent on the federal government according to the developmental stage of their capacity. While outside of the scope of this paper, this is noteworthy as potential option for the development of city-provinces that should be investigated in future research.

Broadbent (2008) asks why we are so "resolutely in thrall to an organizational structure a century out of date", and argues that it is time to build a "new Canada" by introducing these crucial changes (212). However, not all political theorists agree that the creation of city-provinces would even be possible, regardless of how it was undertaken. Andrew Sancton (2008) argues that the boundaries of cities are necessarily flexible, and that they could not be made static in order for big cities to attain provincial status (3). Further, he claims that to establish such concrete boundaries would only reify existing differences between cities, suburbs, and rural areas, which are seen by some as "arbitrary, outdated, discriminatory, and irrelevant" (4). Keil and Young (2003) had similar findings in their research: not only were there significant differences among interviewees about what area actually constituted the city of Toronto, there was a minority opinion that advocated actively for the exclusion of suburbs from a chartered Toronto, as the suburbs "fac[e] a different set of issues than does the city and should, therefore, not be combined with the city" (96). Instead of creating a bounded, rigid city-province, Sancton (2008) argues that the central governments need to exercise their powers more in cities in order to help deal with the problems related to urbanization (131). Addressing some of these arguments, Broadbent (2008) says that the new city-provinces could be created using an opting-in process, instead of determining boundaries from the top-down, in order to be as inclusive as possible (205).

There are also other reasons for why the constitutional entrenchment of big cities would be very difficult to accomplish, and is therefore highly unlikely. Firstly, the provinces will not cede their powers over municipalities, and will guard the current arrangements "jealously" (Dewing, Young, and Tolley 2006, 1; Broadbent 2008, 61). In addition, the smaller provinces would oppose any plan to create city-provinces avidly, seeing it as an attempt to outnumber them and dismiss their regional concerns (Broadbent 2008, 201). The provinces generally see efforts by the federal government to engage with the cities or their issues as an intrusion into their exclusive jurisdiction; indeed, a key reason why past attempts to establish a federal ministry or agency to help deal with urban issues have gone awry was that the provinces viewed this development as the federal governments and municipalities allying against them (Dewing, Young, and Tolley 2006, 4, 7-8).

Slayton (2015) agrees that while constitutional change would be ideal, "the political forces and technical difficulties arrayed against it are too great": any amendment to the constitution requires the approval of seven provinces representing at least $50 \%$ of the 
population $^{10}$, and it would be extremely difficult to get enough provinces on board (4, 233; Dodek 2013, 105; Broadbent 2008, 201; Dewing, Young, and Tolley 2006, 11). As the Macdonald Commission reported, "it is out of the question that the legislative assemblies of such a majority of provinces would agree to this loss of power'" (Dewing, Young, and Tolley 2006, 11; L'Hereaux 1985, 201). Broadbent (2008) claims that those who are most vocally opposed to the empowerment of big cities in the constitution are usually those with the most to lose, including provincial finance departments, provincial bureaucrats, and federal finance ministers, who have "convinced themselves not only that nothing can change, but that nothing should change", and instead prefer to work around constitutional stasis (97, 210, emphasis in original). Given the level of conflict that already exists between the federal and provincial levels of government, it is possible that the addition of city-provinces would only make intergovernmental relations more challenging, complex, and rigid (Dewing, Young, and Tolley 2006, 12).

Several theorists claim that ideally, the best thing for Canada's largest cities would be to bring them to the table and constitutionalize their powers, tools, and obligations, namely by giving them provincial status. Whether or not they agree with this proposal, however, nearly every theorist agrees whole-heartedly that amending the constitution is unlikely in the extreme, because the provinces will vote to maintain their jurisdiction over cities. Many articulate the belief that big cities can work around this problem, and gain additional powers to support the fulfillment of their responsibilities without entrenching them. However, the alternate solutions proposed by various theorists are "tantamount to de facto, if not de jure, constitutional change" (Courchene 2007, 33). Problematically, the ability to enact even smaller, more incremental types of changes always relies on the desire and willingness of the provincial governments to cooperate and delegate significant powers to big cities in the first place, returning us to the original point of difficulty.

What this speaks to is the fact that the constitutional amending formula is too stringent to allow for appropriate action on these issues. Right now there is an inability to amend the constitutional makeup of the country despite clear and consistent need, leaving big cities to attempt to find ways to circumvent these constitutionally imposed restrictions, which results in a weakened and more convoluted democracy for Canada. In discussions of senate and democratic reform, former Senator Hugh Segal has expressed this best: Canada is now in a situation where "the country serves the Constitution rather than the Constitution serving the country" 11 (Broadbent 2008, 167-68). Broadbent (2008) too articulates his frustration with this, declaring that "[o]ur constitutional structure exerts a drag on modernizing our practice" (167). Even Leo (2006), who favors radical decentralization via

7. This specific aspect of the amending formula can be found in Part V, section 38 (1) (b) of the Constitution Act, 1982.

8. This is not a direct quotation of Segal, and no further reference for this statement is provided in Urban Nation. I therefore must entrust the veracity of this comment to Broadbent (2008). 
the inherent flexibility of federalism, says that voluntary arrangements "are not a substitute for a constitutional assignment of responsibilities, nor do they relieve us of the need to consider constitutional changes when circumstances require them" (487). While federalism is prepared to accommodate minority groups, it arguably cannot accommodate majorities such as urban-dwellers - nor should it have to. Therefore, Canada's biggest cities will be best served - and best able to serve the nation - if they are constitutionally entrenched as cityprovinces.

Canada's largest cities are struggling, and they have been for some time. The arguments that I have set out here clearly define a need for change to the structures by which Canada's big cities govern. They face a myriad of difficulties which prevent them from functioning effectively: they are hugely diverse, highly populated, and profoundly distinct from other areas in their surrounding regions; their citizens are underrepresented in parliament; they are disadvantaged fiscally in terms of the tools they are constrained to using; they have little control or autonomy; and lastly, they have minimal ability to contribute to policy- and decision-making even in fields where they have expertise. These problems present severe consequences, including the election of poorly behaved politicians who remain unaccountable, deep frustration for citizens, civil servants, and elected representatives, and worst of all, incompetence and incapacity when it comes to providing essential services. While many have offered solutions that go some of the distance in accomplishing changes for cities, I propose that the constitutional entrenchment of big cities, particularly through the creation of city-provinces, is the best and most democratically sound solution to the resolve the numerous problems that currently exist. Unfortunately, the strict amending formula forecloses on this possibility, leaving cities to consider other, less effective alternatives as a next-best solution, in an attempt to improve the currently unsustainable state of affairs. 


\section{Bibliography}

Andrew, Caroline. 2001. "The Shame of (Ignoring) the Cities". Journal of Canadian Studies, 35 (4), 100-111.

Bradford, Neil. 2002. Why Cities Matter: Policy Research Perspectives for Canada. Ottawa: Canadian Policy Research Network. Discussion Paper No. F23.

Broadbent, Alan. 2008. Urban Nation: Why we need to Give Power Back to Cities to Make Canada Strong. Toronto: HarperCollins.

Canadian Broadcasting Corporation. 2015. "Federal Election Results 2015: Justin Trudeau's Liberals to Form Majority Government". CBC News Canada Votes, October $20^{\text {th }}$. Retrieved from: http://www.cbc.ca/news2/interactives/results-2015/

Courchene, Thomas Joseph. 2005. Citistate and the State of Cities: Political-Economy and Fiscal Federalism Dimensions. Ottawa: Institute for Research in Public Policy.

Courchene, Thomas Joseph. 2007. “Global Futures for Canada's Global Cities”. Policy Matters, 8 (2), June. Ottawa: Institute for Research in Public Policy.

Dewing, Michael, William Robert Young, and Erin Tolley. 2006. Municipalities, the Constitution, and the Canadian Federal System. Parliamentary Information and Research Service.

Dodek, Adam. 2013. The Canadian Constitution. Toronto: Dundurn.

Gander, Kashmira. 2014. Scottish Independence: What is Devo-Max? The Independent, September $15^{\text {th }}$. Retrieved from http://www.independent.co.uk/

Keil, Roger, and Young, Douglas. 2003. "A Charter for the People? A Research Note on the Debate about Municipal Autonomy in Toronto. Urban Affairs Review, 39 (1), 87-102.

Leo, Christopher. 2006. "Deep Federalism: Respecting Community Difference in National Policy". Canadian Journal of Political Science, 39 (3), 481-506.

L'Heureux, Jacques. 1985. "Municipalities and the Division of Powers," in Richard Simeon, ed., Intergovernmental Relations, Royal Commission on the Economic Union and Development Prospects for Canada, No. 63. Toronto: University of Toronto Press, 201.

Libin, Kevin. 2001. "Kevin Libin: The Myth of the Urban-Rural Divide”. National Post, April $10^{\text {th }}$. Retrieved from: http://news.nationalpost.com/news/canada/kevin-libin-themyth-of-the-urban-rural-divide

Sancton, Andrew. 2008. The Limits of Boundaries: Why City-Regions Cannot be SelfGoverning. Montreal \& Kingston: McGill-Queen's University Press.

Slayton, Phillip. 2015. Mayors Gone Bad. Toronto: Viking Canada.

Standing, Guy. 2011. The Precariat: The New Dangerous Class. London: Bloomsbury.

Statistics Canada. 2011. Population and Dwelling Count Highlight Tables, 2011 Census. Population and dwelling counts, for census metropolitan areas and census. Catalogue number 98-310-XWE2011002 in Statistics Canada [database online]. [Accessed April 3rd, 2016].

Statistics Canada. 2011. Population of Census Metropolitan Areas, 2011 Census. Table 0510056 - Estimates of population by census metropolitan area, sex and age group for July 1, based on the Standard Geographical Classification (SGC) 2011, annual (persons), CANSIM (database). [Accessed: April 3rd, 2016]. 